\title{
Factors Affecting Treatment Seeking Patterns amongst Public in Three Selected Areas in Kuantan: Discovery of perceptions (dzan) among community as thought in Islam
}

\author{
Afzan Mat Yusof ${ }^{1,2}$, Syamsul Ahmad Arifin ${ }^{1,2}$, Lokman Md Isa ${ }^{1,2}$ \\ ${ }_{2}^{1}$ Department of Basic Medical Sciences, Kulliyyah of Nursing, Islamic University Malaysia Kuantan \\ 2IIUM Human Cellular and Molecular Biology Research Cluster (iMolec), International Islamic University \\ Malaysia Kuantan
}

\begin{abstract}
Seeking treatment is a vital when an individual falls sick. However, some may not do so perhaps they are ashamed to admitting having shameful diseases or unable to seek and reach help. Negative perception of the community on sensitive diseases like AIDS or sexual transmitted disease (STD) may drive the patients away from seeking treatment and suffer alone. In Islam we are thought to always have positive perceptions (husnu dzan) towards any issues in daily life especially when dealing with human interaction by avoiding bad perceptions (su'u dzan). Thus, this study aims to identify the factors affecting treatment seeking patterns among public in three selected areas in Kuantan, and to explore factors affecting people not able or avoid seeking treatment, also to determine the relationship between treatment seeking patterns and the influential factors ie distance, accessibility and behaviour; attitude to health, healthcare and selfperception. A cross sectional survey was carried out at Taman Gelora, Teluk Cempedak and Terminal Makmur, Kuantan, Pahang. Convenient sampling method was used in this study. 201 respondents participated and answered a semi-structured questionnaire modified from Adamson. Results showed that the data was normally distributed, $50.2 \%$ respondents were male and $58.7 \%$ the total respondents were between 16-26 years old. Majority of the respondents had neutral attitude to health and healthcare, and to self-perception; $94.03 \%$ and $73.63 \%$ respectively. From the results, there were significant association between distance and accessibility, and monthly income, plus between self-perception and demographic data $(p<0.05)$. Self-perception was the most influencing factor as to why people were not able to seek treatment This can be used to educate the community regarding perceptions (khusnu or su'u dzan) and to the policy makers to ensure equal distribution of healthcare services throughout the country.
\end{abstract}

KEYWORDS: Treatment seeking pattern, treatment seeking behaviour, positive perception (khusnu dzan)

\section{INTRODUCTION}

The meaning of health is never fixed. It depends on various understandings. The lay people may think they are healthy if they are not badly sick, some might think that they are healthy if they rarely visit the hospital or clinic, and yet some call themselves healthy if there is no misfortune happened to them ${ }^{2}$. According to Riji (2004), health is a cultural construct and a subjective concept depending on situation, time and perception. People may not define health in relation of disease, instead they may express in terms of spiritual, social, psychological or cognitive dimensions ${ }^{1}$.

Corresponding author:

Muhammad Lokman Md Isa

Department of Basic Medical Sciences,

Kulliyyah of Nursing

IIUM Human Cellular and Molecular Biology Cluster (iMoleC)

International Islamic University Malaysia

Jalan Sultan Ahmad Shah, 25200 Kuantan, Pahang

Telephone: +60129645581

Email: lokman@iium.edu.my
Treatment seeking pattern varies as some prefer self-treatment, traditional healer, or Western medicine; indicating that they realize the importance of taking good care of themselves and make afford to seek treatment ${ }^{5}$. According to Grover et al. (2006), treatment seeking is a dynamic process determined by certain socio-demographical and socio-cultural factors. Socioeconomic has become the evergreen issue for everyone as the cost of living changes from time to time. According to Segall et al. (2000), poor households are burdened by debt often incurred to meet basic consumption needs and are vulnerable to economic blows of all kinds, including family illness ${ }^{3}$. Usually those living in urban areas are more aware and concern about seeking medical help compared to those living in the rural areas because there are better healthcare services there and they can afford the treatment.

Perception on health problem and healthcare services contributes to the treatment seeking behavior $^{4}$. Misperception and misunderstanding continue to become the reason for one to not seek treatment. Wong et al. (2004) reported that public 
awareness, understanding, and attitude towards epilepsy in Chinese had shown discrimination against epilepsy patients in China and Taiwan as compared to United States and the discrimination might be an inherent feature of Chinese cultures regardless of their location in Asia.

Negative perception towards health issues may lead to ignoring the matter completely which can be bad. Community play an important role in portraying a good or bad perception on some sensitive diseases like AIDS or sexual transmitted disease which can cause the sufferer to live in sorrow without courageously seeking for. In Islam we are thought to always have positive perceptions (khusnu dzan) towards any issues in daily life especially when dealing with human interaction by avoiding bad perceptions (su'u dzan). Therefore, this study aims to identify the factors affecting treatment seeking patterns among public in three selected areas in Kuantan, and to discover factors affecting people not able or avoid seeking treatment, and to determine the relationship between treatment seeking patterns and the influential factors (distance and accessibility and behaviours; attitude to health and healthcare and self-perception). This study hopes to provide information on the importance of seeking treatment as soon as possible to minimize the risk of disease progression and complication.

\section{MATERIALS AND METHODS}

\section{Study Design}

A quantitative cross sectional study with convenience sampling was conducted and the data was collected at three selected areas which were Taman Gelora, Teluk Cempedak and Terminal Makmur. The demographic data for this study includes gender, age, monthly income and level of education and the dependant variables were a distance, accessibility and behaviours (attitude towards health and healthcare and self-perception) towards treatment seeking issue. This study has been approved by the International Islamic University Malaysia (IIUM) Ethical Committee (IREC).

\section{Sample Selection}

Sample size of 306 was calculated from the formula adopted from Cochran (http://edis.ifas.ufl.edu) but only 201 respondents were included in this study. Data was collected from December 2015 to February 2016.

\section{Study Instrument}

Data was collected using semi-structured questionnaire modified from Adamson et al. (2003). A pilot study was conducted among 30 participants in order to assess the reliability and validity of the semi-administered questionnaire. The respond rate was $96.67 \%$. The questionnaire consisted of two sections; Section A: demographic data, and Section $\mathrm{B}$ : describing the influential factors why people are not able to seek treatment (distance and accessibility and behaviours; attitude to health and healthcare and self-perception). Incomplete questionnaire were rejected and data was verified.

\section{Statistical Analysis}

Descriptive statistics was used to analyse the data. Data analysis was performed using SPSS version 18.0. Independant T-Test and Kruskal Wallis's Test were used to analyse the relationship of treatment seeking patterns between variables in each group like gender (male and female) and influential factors why people not able to seek treatment.

\section{RESULTS}

Based on sample size calculation, the number of respondent should be 306 but from that only 201 respondents fulfilled the criteria and completed the questionnaire (Table 1). Table 1 shows the demographic data of the participants in this study. The gender distribution in this study is almost equal, most number of participants was from the 18-26 year old group, majority of participants earned less than RM1000.00 and $60 \%$ of the participants received higher education. Table 2 shows the frequency score of 'distance and accessibility to healthcare facility' against 'monthly income' of participants. Most of the participants had easy access to healthcare facilities of which $63.2 \%$ of them earned less than RM1000.00 per month. Only $15 \%$ of the participant had difficulty accessing to the nearest healthcare facilities.

Table 3 shows significant different between Distance and Accessibility with Monthly Income $(p<0.05)$. The highest income group revealed mode of distance and accessibility to get the treatment to be moderate to difficult (4.5)

Table 4 shows frequency score of 'attitude towards health and healthcare'. Most of the participants had 'neutral attitude' only 6\% had 'negative attitude'. Of those reporting 'neutral attitude', almost $60 \%$ were 18-26 years old. Interestingly, no one reported 'positive attitude'.

The results showed that there was no significant difference between attitude to health and health care and gender as evidenced by the p-value is 0.150 (Table 5). Table 4 showed that out of 201 participants, 189 of them had neutral attitude towards health and health care. Out of 189 neutral attitude's respondents, 95 of them were male and 94 were female. Only 12 out of 201 respondents had negative attitude to health and health care which were 6 people from each type of gender. No positive respondent in this study (Table 4 ).

The results showed that there was a significant difference between attitude to health and health care and age of the respondents as evidenced by the $\mathrm{p}$-value is 0.005 (Table 5). Majority of the participants in this study gave neutral feedback on their attitude to health and health care (189 participants). Out of 189 participants, most of them was a group aged between 16-26 years old, (108 
Table 1: Demographics Data of Respondents

\begin{tabular}{clcc}
\hline Category & Description & Frequency (n) & Percentage (\%) \\
\hline Gender & Male & 101 & 50.20 \\
\multirow{2}{*}{ Age } & $18-26$ years & 118 & 58.7 \\
& $26-46$ years & 64 & 31.8 \\
Monthly Income & <MM1000 & 130 & 64.7 \\
& RM1001-RM3000 & 53 & 26.4 \\
& RM3001-RM5000 & 10 & 5.0 \\
& Not Schooling & 4 & 2.0 \\
\hline \multirow{2}{*}{ Level of Education } & Primary Education & 6 & 3.0 \\
\hline
\end{tabular}

$(\mathrm{N}=201)$

participants). The rest who gave neutral feedback were those who aged between 26-46 years old, $(62$ participants) and those who aged between 46-64 years old, (19 participants). However, out of 201 participants there were only 12 participants had negative attitude to health and health care and most of them were from age group of 18-26 years (10 participants). No positive respondents in this study (Table 4).

Table 6 shows frequency score of 'self-perception'. Almost $74 \%$ of the participants had 'neutral selfperception' with male more than female. Only $26.4 \%$ had 'negative self-perception'.
Table 7 showed that out of 201 participants, there were 148 participants had neutral self-perception and only 53 participants had negative selfperception regardless their age. Out of 148 participants with neutral self-perception, most of them were from the group of 18-26 years (79), followed by 26-46 years (52) and 46-64 years (17). In contrary, there were 53 participants had negative self-perception which the main group was the group of 18-26 years (39), followed by $26-46$ years (12) and 46-64 years (2). No one had positive selfperception in this study (Table 6). The results showed that there was a significant difference between self-perception and age of the participants as evidenced by $\mathrm{p}$-value is 0.009 (Table 7).

Table 2: Frequency Score of Distance and Accessibility and Monthly Income

\begin{tabular}{cccc}
\hline & $\begin{array}{l}\text { Easy } \\
\text { (Score: 1-3) }\end{array}$ & $\begin{array}{l}\text { Moderate } \\
\text { (Score: 4) }\end{array}$ & $\begin{array}{l}\text { Difficult } \\
\text { (Score: 5-7) }\end{array}$ \\
\hline Monthly Income & & 37 & 19 \\
< RM1000 & 74 & 9 & 7 \\
RM1001-RM3000 & 37 & 4 & 1 \\
RM3001-RM5000 & 5 & 3 & 4 \\
> RM5001 & 1 & 53 & 31 \\
\hline
\end{tabular}

$(N=201)$

Table 3: Kruskal Wallis's Test between Distance and Accessibility with Monthly Income

\begin{tabular}{lccl}
\hline & median (lqr) & $p$-value & \multicolumn{1}{c}{ Test } \\
\hline Monthly Income & & 0.012 & Kruskal Wallis's \\
< RM1000 & $3.0(1)$ & & Test \\
RM1001-RM3000 & $3.0(1)$ & & \\
RM3001-RM5000 & $3.5(1)$ & & \\
> RM5001 & $4.5(2)$ & & \\
& & & \\
\hline
\end{tabular}

$(\mathrm{N}=201)$ 
Table 4: Frequency Score of Attitude to Health and Healthcare and Demographic Data

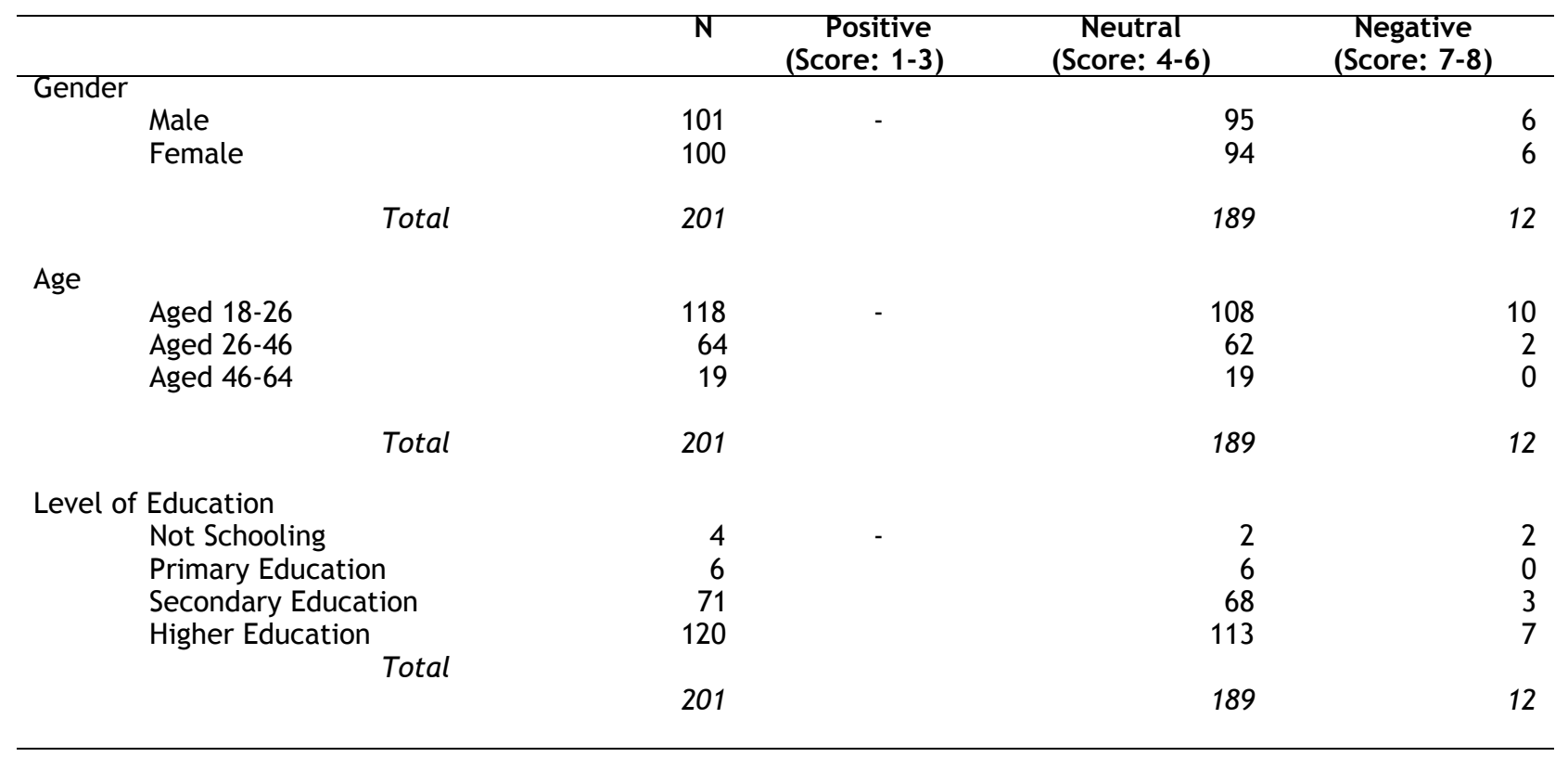

Table 5: Association between Attitude to Health and Healthcare and Demographics Data

\begin{tabular}{|c|c|c|c|}
\hline Demographic Data & Mean(sd)/Median (Iqr)* & $p$-value & Test \\
\hline $\begin{array}{ll}\text { Gender } & \\
& \text { Male } \\
& \text { Female }\end{array}$ & $\begin{array}{l}4.99(0.866) \\
5.16(0.801)\end{array}$ & 0.150 & $\begin{array}{l}\text { Independent } \\
\text { T-test }\end{array}$ \\
\hline $\begin{array}{l}\text { Aged 18-26 } \\
\text { Aged 26-46 } \\
\text { Aged 46-64 }\end{array}$ & $\begin{array}{l}5.0(1)^{*} \\
5.0(1)^{*} \\
5.0(1)^{*}\end{array}$ & 0.005 & $\begin{array}{l}\text { Kruskal } \\
\text { Wallis's Test }\end{array}$ \\
\hline $\begin{array}{l}\text { Level of Education } \\
\text { Not Schooling } \\
\text { Primary Education } \\
\text { Secondary Education } \\
\text { Higher Education }\end{array}$ & $\begin{array}{l}5.5(3)^{*} \\
5.0(2)^{*} \\
5.0(1)^{*} \\
5.0(1)^{*}\end{array}$ & 0.323 & $\begin{array}{l}\text { Kruskal } \\
\text { Wallis's Test }\end{array}$ \\
\hline
\end{tabular}

$(\mathrm{N}=201)$

Table 6: Frequency Score of Self Perception and Demographics Data

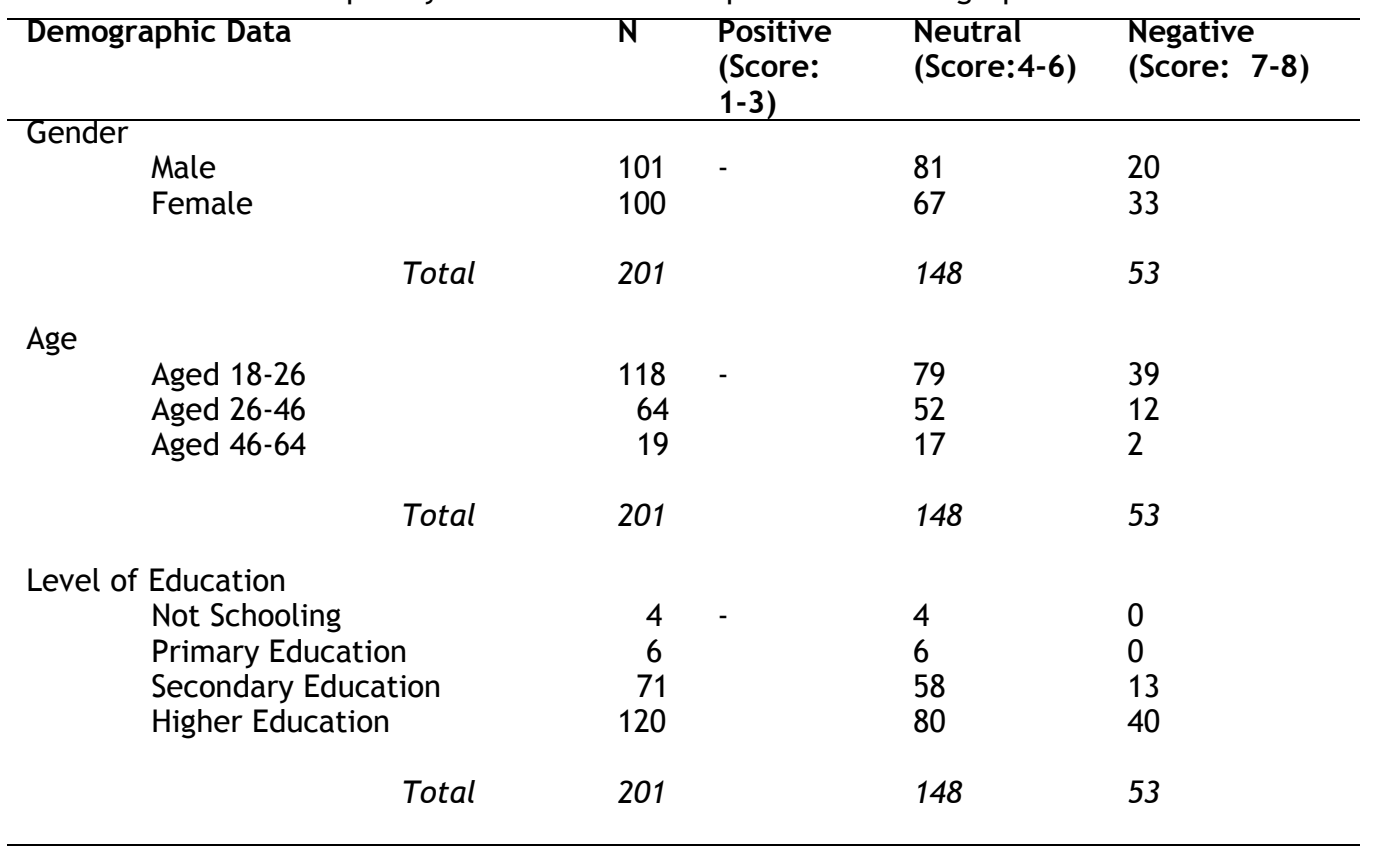


Table 7: Association between Self Perception and Demographics Data

\begin{tabular}{|c|c|c|c|}
\hline Demographic Data & $\begin{array}{c}\text { Mean }(s d) / \text { Median } \\
(\text { lqr })^{*}\end{array}$ & $p$-value & Test \\
\hline $\begin{array}{ll}\text { Gender } & \\
& \text { Male } \\
& \text { Female }\end{array}$ & $\begin{array}{l}5.45(1.170) \\
5.82(1.201)\end{array}$ & 0.026 & Independent T-test \\
\hline $\begin{array}{l}\text { Aged 18-26 } \\
\text { Aged 26-46 } \\
\text { Aged } 46-64\end{array}$ & $\begin{array}{l}6.0(2)^{*} \\
6.0(2)^{*} \\
5.0(2)^{*}\end{array}$ & 0.009 & Kruskal Wallis's Test \\
\hline $\begin{array}{l}\text { Level of Education } \\
\text { Not Schooling } \\
\text { Primary Education } \\
\text { Secondary Education } \\
\text { Higher Education }\end{array}$ & $\begin{array}{l}5.0(2)^{*} \\
4.0(1)^{*} \\
5.0(2)^{*} \\
6.0(2)^{*}\end{array}$ & $<0.001$ & Kruskal Wallis's Test \\
\hline
\end{tabular}

$(\mathrm{N}=201)$

\section{DISCUSSION}

There are many factors influencing treatment seeking patterns but in this study we focused only on several factors such as 'distance and accessibility to health services', 'attitude to health and healthcare' and 'self-perception'. The pattern of health seeking might vary according to socio-economic circumstances and other determinants. ${ }^{2}$ The results demonstrate there is a significant difference between distance and accessibility and monthly income. In this study, majority of the respondents had easy access to go to the nearest hospital or any healthcare institution. In contrast, out of 201 respondents, there were 31 of them had difficulty accessing to the nearest hospital because; they stayed more than $20 \mathrm{~km}$ from the nearest hospital, no transport from home, and no public transportation available from home. Arif (2002) explained that urban areas across all states had higher percentage of population within $5 \mathrm{~km}$ of healthcare facilities when compared to rural areas, especially Sarawak, Sabah and Pahang which are relatively poorly served.

Age was statistically significant factor related to attitude to health and healthcare. The group aged 18-26 was the highest number of participation where this age group is open and eager. ${ }^{8}$ This is one of the contributing factors for that group to become the leading group of having neutral attitude towards health and healthcare. Those in the 18-26 year old group will focus on healthcare as opposed to sick care.

Out of 53 respondents who had negative selfperception, women had the highest proportion compared to men. Women often have poorer health relative to men of the same household and social group. ${ }^{10}$ Referring to the social context of women's lives, women are more likely to experience more significant detrimental consequences plus they are also disadvantaged by other forms of impoverishment in areas such as literacy, education, skills, employment opportunities, mobility, political representation, and pressures on their available time and energy linked to role responsibilities. ${ }^{10}$

When the health-seeking patterns of men and women are compared, females are significantly less likely to seek care than males in both member and poor non-member households ${ }^{11}$. However, the relationship between gender and health is complex and changes over the individual's life time, between generations in different historical epochs, across cultures and geographical regions. ${ }^{10}$

With regards to the age and level of education, both had significant differences with self-perception. The most significant demographic factors that influence self-assessed health are age and level of education. ${ }^{12}$ In this study, older people may perceive their health as worse than young ones due to presence of chronic diseases and physical conditions which are more often present in older age so that their tendency to seek for health is higher. $^{12}$

With regards to level of education, majority of the respondents had neutral perception. Generally, higher educated people have better mind setting because their level of thinking is widen. If a higher educated person has any health impairment, he or she is more likely to seek medical help sooner. ${ }^{13}$ As mentioned above, the causal relation between education and health arises because a higher education leads to a healthier life style and because higher educated people are better able to gather, to process and to interpret information about healthy behaviour. ${ }^{13}$

This study showed that most of the participants have negative or neutral self-perception towards health and healthcare. This issue could worsen if more people ignore and feeling upset with the 
IMJM Volume 17 Special Issue No 2

system. Therefore more intense awareness program based on Islamic teaching/perspective should be carried out in the community to address health issue and stigma. Negative or neutral perception towards health and healthcare may be inherited from one generation to another generation without knowing the real fact, yet with full prejudice and negativity. First verse in Quran already asked the believers to find the knowledge and wisdom. The lack of knowledge among community will lead to negative perception and discrimination to the sufferer of certain disease.

\section{CONCLUSION}

This study finds that distance, accessibility and self -perception as the most commonly perceived influencing factors that affect treatment seeking patterns among public in these three selected areas (Taman Gelora, Teluk Cempedak and Terminal Makmur, Kuantan, Pahang). This findings could be used to educate the community regarding perceptions (khusnu or su'u dzan) and to the government to ensure equal distribution of healthcare services throughout the country. Preventive programs such as health promotion campaign concerning the importance of seeking early treatment must be done in order to increase awareness.

\section{ACKNOWLEDGEMENT}

The authors are very grateful to the public participants from Taman Gelora, Teluk Cempedak and Terminal Makmur Kuantan for their kind cooperation during the study period. The technical assistance from lecturers, assistant lecturers, clinical instructors, and staffs in Kulliyyah of Nursing (IIUM) are highly appreciated.

\section{REFERENCES}

1. Riji HM. Social and behavioural determinants in public health: current perspectives. Community Health J. 2004.

2. Grover A, Kumar R, Jindal SK. Sociodemographic determinants of treatmentseeking behaviour among chest symptomatic. Indian J Community Med. 2006; 31:145.

3. Segall M, Tipping G, Lucas H. Healthcare seeking by the poor in transitional economies: the case of Vietnam. 2000. Available from ttps: / / assets.publishing.service.gov.uk/ media/57a08d7fed915d3cfd001a6e/R7239.pdf. Accessed December 16, 2010.

4. Patel S. A multilevel exploration of treatment seeking behaviour of disabled persons in India. Internet J Third World Med. 2008; 7:1-7.

5. Wong V, Chung B, Wong R. Pilot survey of public awareness, attitudes and understanding towards epilepsy in Hong Kong. Neurol Asia. 2004; 9:21-7.

6. Adamson J, Ben-Shlomo Y, Chaturvedi N, Donovan J. Ethnicity, socio-economic position and gender: do they affect reported health- care seeking behaviour? Soc Sci Med. 2003; 57:895-904.

7. Arif MT. The Malaysian health system of the future in the context of globalisation. Jurnal Kesihatan Masyarakat Isu Khas. 2002.

8. Coates J. Generation Y: the millennial. 2007. Available from http://honolulu.hawaii.edu/ intranet/committees/FacDevCom/guidebk/ teachtip/GenY.htm. Accessed April 17, 2011.

9. Mocke D. Understanding generation Y. 2010. Available from http: / /www.sustainableemployee-motivation.com/generation-Y.html. Accessed April 17, 2011.

10. Nzioka C. Men in gender healthcare policy. 2005. Available from http: / /www.aecid.es/ export/sites/default/web/galerias/programas/ Vita/descargas/ponencia Nzioka-2.pdf. Accessed April 17, 2011.

11. Ahmed SM, Adams AM, Chowdhury M, Bhuiya A. Gender, socioeconomic development and health -seeking behaviour in Bangladesh. Soc Sci Med. 2000; 51:361-71.

12. Kaleta D, Polańska K, Dziankowska-Zaborszczyk E, Hanke W, Drygas W. Factors influencing selfperception of health status. Cent Eur J Public Health. 2009; 17:122-7.

13. Groot W, Maassen van den Brink H. 4.A. What does education do to our health? In: Measuring the effects of education on health and civic engagement: proceedings of the Copenhagen symposium 2006: 355-63. 